УДК 070(477.54):365.2 «1920-1939»

https://doi.org/10.34142/2313-2345.2019.56.13

Мартинова I. C. кандидат історичних наук, доцент кафедри історії України Харківського начіонального педагогічного університету імені Г.С.Сковороди https://orcid.org/0000-0001-7715-9245

\title{
«ЖИТЛОВЕ ПИТАННЯ» В ХАРКОВІ У 1920-30-ті РОКИ В ДИСКУРСІ ПРЕСИ
}

У статті проаналізовано відображення в республіканській та місиевій пресі проблеми забезпечення житлом мешканців Харкова - великого промислового иентру, столиці радянської України з 1919 по 1934 роки.

Стрімке зростання населення Харкова, викликане будівництвом промисловості та перетворенням його на столицю радянської Украйни, спричинило житлову кризу. Різноманітні аспекти житлової проблеми міста Харкова розглядалися як у місиевій пресі, представленій газетами «Харківський пролетар» (орган Харківського окружного комітету КП(Б)У), «Харьковский рабочий» (орган Харківського міського комітету КП(б)У та міської ради), «Пролетарий», так $і$ в пресі загальноукраїнського значення - республіканській газеті «Вісті ВУЦВК». Центральною темою публікацій були масштаби й засоби подолання житлової кризи у місті. Причиною кризи преса визначала стрімке зростання робітничого класу $i$ «пережитки минулого». Як засіб вирішення проблеми у 1920-ті роки пропагувалося кооперативне будівництво, у 1930-ті роки більше уваги приділялося новобудовам та питанням якості будівництва. Хоча радянська преса перебувала під партійним контролем, але у 1920-ті роки допускалися критичні публікачії щодо кризової ситуаиії з жстлом, безгосподарності $i$ розхлябаності окремих осіб і діячів. Критикувалася навіть ідея і практика будинків-комун. Преса формулювала проблему, ї̈ масштаби, інформувала про можливі засоби їх вирімення, які пропонували державні органи; повідомляла про те, яке житло хотіли б отримати робітники, що свідчить про зворотній зв'язок між суспільством і пресою. Таким чином, наприкінці 1920-х - на початку 1930 рр. такі риси радянської преси, як монологічний характер, обмежена динамічність, непрозорий характер функиіонування ще не почали повною мірою функиіонувати.

Ключові слова: «житлове питання», преса радянської України, Харків, житлова криза, пролетарiam.

The article analyzes the reflection of the problem of providing housing for residents of Kharkiv - a major industrial centre, the capital of Soviet Ukraine from 1919 to 1934 in the republican and local press. The task of the press is to identify the problems existing in society, to articulate them, to influence public opinion on the reasons for their appearance, or the means of their solution.

In the period under study, the traditional tasks of the press changed, periodicals were transformed from an organ of public opinion into an ideological propaganda tool for consolidating Bolshevik power. The 
rapid growth of Kharkiv population, caused by the construction of industry and its transformation into the capital of Soviet Ukraine, provoked a housing crisis. This was the subject matter of the discussion in the press. How much did the then Soviet press serve to publicize and search for a solution to this problem?

Various aspects of the housing problem of the city of Kharkiv were dealt with both in the local press, represented by the newspapers The Kharkiv Proletarian (the body of Kharkiv Regional Committee of the $C P(B) U$ ), The Kharkiv Worker (the body of the Kharkov City Committee of the Communist Party (B)U and the city council), The Proletarian, and in the Ukrainian-wide press, that is in the republican newspaper The Bulletin of the AUCEC (All-Ukrainian Central Executive Committee). The problem was most actively covered in the newspaper The Kharkiv Proletarian in 1925-28 and in The Kharkiv Worker in 1933-34 respectively.

The subject matter of the publications testifies that the central issue was the scale and means of overcoming the housing crisis in the city. The cause of the crisis determined by the press was the rapid growth of the working class and the "remnants of the past." Cooperative construction was promoted in the 1920s as a means of solving the problem; more attention was paid to new buildings and construction quality issues in the 1930s. Although the Soviet press was under party control, the critical publications about the housing crisis, the mismanagement and laxness of officials and citizens were quite frequent in the 1920s.

Even the idea and practice of houses-communes was criticized. The press formulated the problem, its scale, announced the possible ways to solve it, which were offered by state bodies; reported on what kind of housing workers would like to receive, indicating feedback from the society and the press. Thus in the late 1920s - early 1930s such features of the Soviet press as monological character, limited dynamism, nontransparent character of functioning did not begin to operate to the full extend.

Keywords: "housing issue», the press of Soviet Ukraine, Kharkiv, housing crisis, proletariat.

Постановка проблеми. Преса в усі часи $є$ лакмусовим папірцем, який демонструє проблеми, що існують в суспільстві, вона їх артикулює, формує суспільну думку щодо причин їх появи або засобів вирішення. У період, що вивчається, відбувалося перетворення періодики з органа громадської думки на ідеологічно-пропагандистський інструмент закріплення більшовицької влади. В радянські часи матеріали газет і журналів в основному були ілюстрацією досягнень радянської влади й Компартії. У пострадянський період радянська преса стала об'єктом критики і недовіри. Але усвідомлення загальної заангажованості та критичний підхід до публікацій того періоду дозволяють вилучити не тільки важливі факти, а й оцінити суспільні настрої і проблеми. Значні можливості в цьому надає вивчення української преси 1920-1930-х років, коли тотальний контроль над пресою тільки встановлювався, ще тривала дискусія про роль радянської преси у будівництві комунізму.

В Україні становлення партійно-радянської преси хронологічно збігається 3 часом стрімкого зростання населення Харкова, викликаного будівництвом радянської промисловості та перетворенням його на столицю радянської України. Житлова політика радянської влади і процес індустріалізації викликали появу так званого «жит- лового питання». Якою була реакція радянської української преси на проблему забезпечення житлом населення міста і перш за все провідного класу радянського суспільства - пролетаріату? Наскільки пресові матеріали співпадали 3 партійними настановами у висвітленні певних проблем?

Наукова новизна роботи полягає в тому, що авторка дослідила реакцію радянської преси на важливу соціальну проблему - забезпечення житлом пролетаріату великого промислового міста, тогочасної столиці радянської України. Час, що досліджується, був знаковим - як для перетворення робітників на нову провідну верству українського суспільства, так і для становлення української радянської преси. Проаналізовано форми і засоби подання в пресі проблем житлового будівництва.

Стан наукової розробки теми. Становлення радянської преси в Україні та висвітлення в ній партійної політики та різноманітних проблем українського суспільства вивчається в українській історіографії. Так у публікаціях О. Коляструк вивчалося місце преси в суспільному житті України в 1920-30-ті роки [Коляструк О. 2001; Коляструк О. 2003].

Матеріали преси як джерело використовувалися дослідниками повсякденного життя різних верств українського суспільства періоду становлення радянської влади в 
Україні. Зокрема, проблеми забезпечення їх житлом вивчалися у статтях та монографіях М. Борисенка [Борисенко М. 2009], Р. Любавського [Любавський Р. 2016], О. Мовчан [Мовчан О. 2011] та інших, але ж проблематика газетних статей, форми подачі матеріалу окремо не вивчалися.

Мета статті - проаналізувати відображення в республіканській та місцевій пресі проблеми забезпечення житлом мешканців Харкова - великого промислового центру, столиці радянської України з 1919 по 1934 роки.

Виклад основного матеріалу. Різноманітні аспекти житлової проблеми міста Харкова розглядалися як у місцевій пресі, так і в пресі загальноукраїнського значення. Всеукраїнською республіканською газетою були «Вісті ВУЦВК», видавництво якої почалося у Києві у 1919 р., а 31920 р. було перенесено в Харків. Від червня 1934 р. газета знову друкувалася у Києві. У липні 1938 р. змінила назву на «Вісті Рад депутатів трудящих УРСР». Газета публікувала декрети, накази та постанови Уряду УСРР, звіти про з'їзди рад з аналізом прийнятих рішень. Серед постійних рубрик - «Міжнародні новини», «Столичний день», рубрика оголошень. Із розвитком газети з'являється щотижневий додаток «Література. Наука. Мистецтво», пізніше - «Культура і побут». Газета видавалася під редакцією В. Блакитного, потім - Є. Кас'яненка. 14 травня 1941 p. «Вісті» було об'єднано з центральним органом партії - газетою «Комуніст», яка виходила з липня 1918 р. До всеукраїнських видань належала також робітнича газета «Пролетар», яка була органом Всеукраїнської Ради професіональних спілок i виходила з 1926 по 1932 pp

Місцева преса представлена була газетою «Харківський пролетар» - органом Харківського окружного комітету КП(Б)У, яка виходила з 1917 по 1941 р. і до 1930 року мала назву «Харьковский пролетарий», газетою «Харьковский рабочий» - органом Харьківського міського комітету КП(б)У та міської ради, яка виходила з 1934 по 1939 роки. Газета «Пролетарий», що виходила 3 червня 1920 р., була Органом Харківського губернського виконкому Ради робітничих, селянських та червоноармійських депута- тів. 31921 р. вона стала органом губвиконкому КП(б)У, губвиконкому Рад, ради профспілок і Харківської міської ради. На шпальтах цих видань знайшла відображення одна 3 важливих проблем тогочасного життя міста - забезпечення житлом провідної верстви радянського суспільства - пролетаріату.

Одним із засобів демонстрації переваг диктатури пролетаріату було забезпечення трудящих нормальним житлом. В. Ленін вказав метод вирішення цього завдання: переселення робітників у помешкання буржуазії. В 1920 році цей процес розпочався у Харкові, про що зазначено було в статті В. Верхотурського [Верхотурський В. 1920: 3]. Із статті видно, що дії влади не викликали значної підтримки у робітників міста i причиною того була невпевненість їх у міцності радянської влади, небажання змінювати звичний уклад життя. Уже в 1923 році в газеті «Пролетарий» порушується проблема житлового забезпечення населення міста, поганих умов життя. У 1924 році журналісти місцевої преси проблему починають маркувати як кризу [Как ослабить жилищний кризис... 1924; Лабораторин 1924: 11-12]. В їх публікаціях було відзначено, що Харків був серед міст, які не дуже постраждали від воєнних дій, але в місті бракувало житла до війни, будувалися в основному дерев'яні, «маломіцні будинки». Так за переписом 1923 року з загального числа 35145 будинків 24746 були маломіцними, i до 1924 року будівництво практично не відбувалося, наявний житловий фонд чим далі тим більше не задовольняв потреби міста, а кількість городян постійно зростала. Дійсно, з 1923 по 1926 рік чисельність мешканців міста збільшилася на 17\% [Коваленко I. 1926: 7].

Наступного року обговорення проблеми переходить на шпальти всеукраїнської преси. Так в газеті «Комуніст» на початку жовтня 1925 року було надруковано велику статтю голови Всеукраїнського виконавчого комітету Г. І. Петровського, в якій було накреслено план і перспективи житлового будівництва у Харкові, підкреслювалося, що Харків $є$ промисловим центром, столицею республіки, тому житлова питання тут потребує особливої уваги. 
Через два тижні тему підхопили «Вісті ВУЦВК», в яких стан житлового забезпечення в Харкові також був визначений як кризовий, було намічено засоби вирішення проблеми. Відзначалося, що житлові кооперативи вели будівництво, але це не вирішувало проблеми. Тому ВУЦВК надіслав пропозиції до РНК і Держплану про збільшення коштів на житлове будівництво Харкова [Житлова криза в Харкові 1925].

Одночасно до теми житлової кризи у місті повертається і місцева преса - «Харьковский пролетарий». Впродовж 1925-1927 років засоби вирішення житлової проблеми у Харкові та їх результативність постійно обговорювалися на сторінках як місцевої, так і республіканської преси. На початку січня 1927 року у «Харьковском пролетарии» відзначалося, що підприємства будували замало через брак коштів, так Південмаштрест виділив ХПЗ 1 млн крб. і на ці кошти було побудовано 2 будинки, розміщено до 300 осіб, хоча в цей же час кількість робітників на ХПЗ збільшилася на 700 осіб, на заводі «Серп і молот» - на 670. Газета пропагувала такий засіб вирішення проблеми як кооперативне будівництво [2 000000 руб. на рабочее... 1927]. Про успіхи житлової кооперації під керівництвом профспілок йшлося в статті «Профсоюзи за стройкой» [Профсоюзи за... 1927], відзначалася діяльність кооперативів «Червоний швейник», «Зв'язок», «Харьківський хімік», «Канатчик» та ін. Заявок на будівництво було подано 6300, задовольнили 1600. Проблема нестачі житла продовжувала вирішуватися за рахунок ущільнення, хоча в 1927 році на робітниче житло було виділено 2 млн крб.

Щодо кооперативного будівництва, то місцева преса відзначала в ньому одну значну проблему, а саме, через брак коштів робітники не мали можливості вступати до кооперативів і тому із 80 тис. кв. м житла, побудованих кооперативами на 1928 рік 36 тис. належало службовцям. Автором статті це визнавалося як негативний факт, бо за партійним настановами пріоритетом у забезпеченні житлом мали бути робітники.

У 1928 році житлова криза в місті дедалі загострювалася. У місцевій пресі відзначалося, що в особливо скрутних умовах перебували робітники підприємств республіканського значення, 12 тис. осіб жили в підвалах, коморах, ванних кімнатах, на людину припадало всього 5,6 кв.м житла, а то i менше. Окружний виконавчий комітет виділив на житлове будівництво 1,5 млн крб, але їх не вистачило, тому було прийнято рішення про звернення до республіканських органів [Удар по житло кризі 1928]. У цих умовах місцева влада прийняла рішення про перехід до квартальної забудови, будівництва великих багатоквартирних будинків [Будинки в 300-400 квартир 1928].

Під впливом комуністичної ідеології 3'явилася ідея побудови будинків - комун, розгорнулася дискусія між прибічниками різних поглядів на урбанізацію. Була сформульована концепція соціалістичного розселення та «соціалістичного міста», згідно 3 якою поруч із новими промисловими підприємствами мали будуватися нові поселення для робітників та їхніх родин, транспортне забезпечення й система розподілу. Харківська преса також відреагувала на обговорення, тим більше що ідею створення будинків-комун намагалися втілити й у Харкові. На сторінках газети «Пролетар» [Ми проти і швейцарських... 1928] розгорнулася дискусія про доречність такої форми побудови і розселення громадян. Дописувачі виступили проти будинків-комун (такий був збудований між Лермонтовською і Толкачівською вулицями). Цей будинок вважали казармою, місцем постійних сварок, а не комуною. На думку автора статті, спільна кухня 3 великою плитою стала «місцем бою для господарок». Ще однією формою домівки для робітників було обрано англійський котедж, і така забудова практикувалася в Харкові, було побудовано близько 35 котеджів. У зазначеній статті критик будинків-комун не вважав і будинки-котеджі ідеалом соціалістичного будівництва. А от створення «соціалістичного міста», багатоквартирні висотні будинки викликали велике захоплення. Автор висловлювався від імені робітників і наголошував, що їх більше приваблюють окремі квартири з кухнями, певні зручності як у будинках, так і навколо. Робітників турбувала наявність шкіл та дитсадків, лікарень, а також місць для прогулянок, відпочинку. Автор статті нама- 
гався підкреслити, наскільки важливим для робітника $\epsilon$ особистий приватний простір, що певною мірою вступало в суперечність iз концепцією колективного співіснування.

Реалізація проекту «соціалістичного міста» відбувалася у Харкові паралельно 3 будівництвом індустріального велетня ХT3. Увага преси була привернута не тільки до самого заводу, але й до будівництва «Нового Харкова» - містечка робітників [Будування міста... 1930].

У фокусі уваги харківської преси перебували не тільки новобудови, але й проблеми уже наявного житлового фонду. Так в статті Я. Орлова «Впорядкувати житлове господарство Харкова» наголошувалося, що житлове господарство столиці України знаходиться в незадовільному стані, ремонтна кампанія 1932 року пройшла невдало, хоча упорядкування старого житла, його відбудова, ремонт могли б значно поліпшити житлове забезпечення мешканців міста. В якості засобу забезпечення житлом трудящих автор пропонував скорочення площ, які займають різноманітні установи і організації, виселення так званих «позбавленців». Привертав увагу автор і до проблем приватного сектора на околицях міста, якому міська влада зовсім не приділяла уваги, хоча в таких будинках жило багато трудящих.

Стаття також інформувала про зміни в керівництві житловим фондом: житлотрести керували житловими приміщеннями i ïx експлуатацією; торгтрести - торгово-промисловим, складськими i конторськими приміщеннями; райради - приватними будинками. Автор закликав трудящих і місцеві органи влади приділити упорядкуванню житлового господарства в другій п'ятирічці особливу увагу. У статті також відзначалося, що масштаби нового житлобудівництва поки не вирішили житлової кризи [Орлов Я. 1933].

У 1933-1934 рр. увага преси до житлових проблем посилюється. Про актуалізацію житлової проблеми в місті в 1930-х роках свідчить і той факт, що iі обговорення в буквальному сенсі виходить на перші сторінки місцевої преси, тоді як в попередні роки це були 3-4 сторінки. Стаття «Жилищное строительство на уровень задач второй пятилетки» була написана в пропагандистському стилі партійної «передовиці» і розміщена на першій сторінці «Харьковского рабочего». У ній наголошувалося, що «житлове питання» було предметом обговорення XVII з'їзду партії і реалізація його рішень в УСРР знаходиться під особистим контролем П. Постишева та Л. Кагановича, що мало продемонструвати турботу партії і уряду про соціальні потреби трудящих. Було зазначено, що 1934 рік стане переломним у рішенні житлових проблем, критикувалися попередні форми керівництва процесом житло будування і житлокористування - трести, пропонувалося їх позбавитися. [Жилищное строительство... 1934].

У статтях «Выполнить програму жилищного строительства и ремонта», «Строить быстро, дешево, красиво» та інших, також розміщених на першій сторінці «Харьковского рабочего», розглядалися конкретні проблеми житлобудування міста. В публікаціях відзначалося, що житлова криза продовжується. 3'явилася нова тематика у висвітленні житлового питання, а саме критика якості новобудов, діяльності організацій, відповідальних за процес житло будування - житлобудівних кооперативів, трестів, Держбудконтролю. Штурмовщина, крадіжки, нестача будівельників при великій кількості начальників, нестача будматеріалів, низька якість кладки цегли, дерев'яних конструкцій - до цих та інших недоліків привертала увагу місцева преса. 3'ясувалося, що деякі ЖБК будують домівки взагалі без планів і проектів. Для підвищення якості житлобудування i ремонту «Харьковский рабочий» закликав встановити громадський контроль над процесом [Выполнить програму... 1934; Строить быстро.. 1934; Г. Д. 1934].

Висновки та перспективи подальших досліджень. Житлові проблеми населення міста Харкова були об'єктом пильної уваги як місцевої, так і республіканської преси 1920-1930-х рр. Особливо активно проблема висвітлювалася у 1925-1928 рр. у газеті «Харьковский пролетарий» та у 1933-1934 pр. у газеті «Харьковский рабочий». Періодично до проблем житлового будівництва у Харкові зверталося республіканське видання «Вісті ВУЦВК». Щодо 
тематики публікацій, то центральною була тема наявності і засобів подолання житлової кризи у місті. Причиною кризи преса визначала стрімке зростання робітничого класу і «пережитки минулого». Як засіб вирішення проблеми у 1920-ті роки пропагувалося кооперативне будівництво, у 1930-ті роки більше уваги приділялося новобудовам. Хоча радянська преса знаходилася під контролем держави, але в 1920-ті роки в ній були критичні публікації щодо кризової ситуації з житлом, безгосподарності і розхлябаності окремих осіб і діячів. Критикувалася навіть ідея і практика будинків-комун.

Для більш повного розкриття теми необхідно проаналізувати публікації спеціальних часописів, таких як «Жилищная кооперация Украины», «Строительная промышленность», «Архітектура радянської України».

\section{ЛІТЕРАТУРА}

Борисенко М. Житло та побут міського населення України у 20-30-ті рр. ХХ століття: Монографія. К.: ВД «Стилос», 2009. 357 c.

Будинки в 300-400 квартир // Робітнича газета «Пролетар». 1928. 24 жовтня.

Будування міста навколо Тракторного заводу //Вiсті ВУЦВК. 1930. 8 квітня

Верхотурский В. Заседание Харьковского городского совета по вопросам переселения робочих в квартиры буржуазии //Пролетарий. 1920. 24 июня. С.3.

Вологодиев I., Каплунов I. Комунальне господарство міст України. Харків:Держвидавництво «Господарство Украӥни». 1930. 68 с.

Выполнить програму жилищного строчтельства и ремонта// Харьковский рабочий. 1934. 27 апреля.

Г. Д. Строителям ТЭЦ - культурное общежитие // Харьковский рабочий. 1934. 23 квітня.

Гофман. Индивидуальное строительство закабаляет рабочих // Жилищная коопераџия Украины. Х., 1927. № 4. C. 28-38.

Данільєва Ю. Г. Житлова проблема в украӥнському радянському місті у 20-30-ті рр. ХХ століття // Вісник Східноукраӥнського начіонального університету ім. В. Даля. 2011. №11. Ч.1. С.28-38.

2000000 руб. на рабочее жилстрочтельство в Харькове // Харьковский пролетарій. 1927. 8 января.

Диденко Е. Жилищное строчтельство в столичном Харькове (1927-1934) // Традииії $і$ новації у вищій архітектурно-художній освіті: збірка наукових праиь / Харківська державна академія дизайну та мистеитва. Харків: 2012. Вип. 6. С.69-78.

Дорого коштує житлове будівниитво // Робітнича газета «Пролетар». 1928. 6 січня

Друзь Ф. Жилищнная кооперачия Украины к десятой годовщчине Октябрьской револющии // Жилищчная кооперация Украины. 1927. № 15. С. 6-19.

Дубровский. Мнимые выгоды индивидуального строительства // Жилищная кооперация Украины. 1927. № 4. C. 28-39.

Жилищный вопрос: Сборник декретов, распоряжений, инструкиий с разъяснениями. Х., 1921. 171c.

Жилищное строительство на уровень задач второй n'ятилітки// Харьковский рабочий. 1934. 29 марта
Жилищно-коммунальное хозяйство СССР. Справочные данные. Москва: НИФ СССР Госфиниздат, 1936. 55 таблич

Житлова криза в Харкові // Вісті ВУЦВК. 1925. 15 жовтня.

Історія міста Харкова ХХ століття [О. Н. Ярмиш, С. I. Посохов, А.І. Епштейн та ін.] Х.: Фоліо, Золоті сторінки, 2004. 686 c.

Как ослабить жилищңний кризи в Харькове//Харьковский пролетарій. 1924. 1 авг.

Каплунов І., Букштейн Д. Житлові умови міського пролетаріату УСРР // Вісник статистики. 1930. № 6. C. $48-59$.

Коваленко I. 3. Харків. Населення, житлові умови, бюджет дрібних володінь. Х.: Хар.окр.стат.бюро, 1926. Bun.3. C.7.

Коляструк О. А. Пресса в умовах «наступу соціалізмy» (кінець 20-x - початок 30-х рр.) URL:file:///D:/ System/Downloads/Nzvdpu_ist_2001_3_28\%20(1).pdf

Коляструк О.А. Преса в радянській політичній системі у 20-30-ті pp. ХХ ст.// Наукові записки Вінницького державного педагогічного університету імені Михайла Коиюбинського. Серія : Історія. 2003. Bun. 5. C. 104-110./ URL: http://nbuv.gov.ua/UJRN/Nzv dpu ist $2003 \quad 5 \quad 28$

Лабораторин. К разрешению жилищного кризисна //Жилище рабочего. 1924. №1. C.11-12.

Левитан Й. Війна поверхів // Харківський пролетар. 1932. 7 листопада

Любавський О. М. Повсякденне життя робітників Харкова в 1920-ті-початку 1930-х років / наук. ред. Л. Ю. Посохова / Передм. О.А. Коляструк Х.: Раритети Украӥни, 2016. 226 с.

Марзеев А. Н. Новые рабочие жилища на Украине Х., 1928. 121c.

Местеикий Я. Жилищное хозяйство Украины. Х.: Гос. изд-во Украины, 1929. 168 с.

Меерович М.Г. Наказание жилищем: жилищная политика в СССР как средство управления людьми (1917-1937 годы). М.: РОССПЭН; Фонд Первого Президента России Б.Ельциина, 2008. 303 с.

Ми проти і швейцарських домиків, $і$ будинків - комун // Робітнича газета «Пролетар». 1928. 31 жовтня 
Мовчан О.М. Повсякденне життя робітників УСРР.1920-ті рр. К.: Інститут історії України НАН Украӥни, 2011. 312 с.

О новых течениях в разрешении жилищного вопроса // Жилищчная кооперациия Украины. 1927. № 11. С. 30-38.

Обмен жилой площуадью // Жилищная кооперация Украины. 1927. № 3. С. 48-55.

Орлов Я. Впорядкувати житлове господарство Харкова // Харківський пролетар. 1933. 6 січня

О. Г. Жилищное строительство на уровень задач второй пятилетки// Харьковский рабочий. 1934. 29 марта

Охитович М. Заметки по теории расселения // Современная архитектура. 1930. № 1-2. C. 45-49.

План жилищного и коммунального строчтельства г. Харькова и его пригородной зоны. Второе пятилетие(1933-1937 г2.) Под общей редакцией Шахматова М. Г. и Зигермана И. Н. [Ч.1.]- [Харьков]. Редакичионно-издательский сектор Харьковского Горсо- вета. 1932. Харьковская городская плановая комиссия. Материаль к 1 варианту пятилетнего плана хозяйственного и национально-культурного строительства. Bып. 1. [Ч.1.]

Профсоюзы за стройкой// Харьковский пролетарий. 1927. 16 сентября.

Степанчук Ю. С. Періодичні видання як історичне джерело у дослідження суспільного життя УСРР у 20-х роках XX століття // Історична пам'ять. 2012. Bun. 28. C. 155-160. URL:

http://nbuv.gov.ua/UJRN/Ip_2012_2_18

Строчть дешево, хорошо, красиво // Харьковский рабочий. 1934. 29 мая.

Удар по житло кризі // Робітнича газета «Пролетар». 1928. 13 жовтня.

Хмурий В. Ще до архітектурного обличчя міста // Вісті ВУЦВК. 1925. 1 листопада.

Чурилов I. М. Забытые общежития //Харьковский рабочий. 1934. 29 марта.

\section{REFERENCES}

Borisenko, M. (2009)/ Zhytlo ta pobut miskogo naselennya Ukrayiny u 20-30-ti rr. XX stolittya. [Housing and Life of the Urban Population of Ukraine in the 20-30's. XX Century]K.: VD "Stilis".

Budynky v 300 - 400 kvartyr (1928) [Houses in 300-400 apartments]. Robitnycha gazeta «Proletar», 24 zhovtnya [Worker's newspaper Proletar, October 24 th].

Buduvannya mista navkolo Traktornogo zavodu (1930) [Construction of the city around the Tractor Plant]. Visti VUCzVK, 8 kvitnya - VUTSVK news, April 8 th.

Verkhoturskiy V. (1920)Zasedanie xarkovskogo gorodskogo soveta po voprosam pereseleniya robochix v kvartiry burzhuazii [Session of the Kharkiv City Council on the resettlement of workers in the apartments of the bourgeoisie]. Proletarij-Proletarian, June 24 th.

Vologodtsev, I. Kaplunov, I. (1930). Komunalne gospodarstvo mist Ukrayiny [Municipal economy of Ukrainian cities]. Kharkiv: State Publishing House "The Economy of Ukraine", 68

Vypolnit programu zhilishhnogo stroitelstva i remonta (1934). [Run the program of housing construction and repair]. Xarkovskij rabochij, 27 aprelya. - Kharkov worker, April 27th.

G.D. (1934)/ Stroitelyam tec - kulturnoe obshhezhitie [The builders of CHP - a cultural hostel]. Xarkovskij proletarij-Kharkov worker, 23 April.

Hoffman. (1927) Individualnoe stroitelstvo zakabalyaet rabochix [Individual construction enslaves workers]. Zhilishhnaya kooperaciya ukrainy - Housing cooperation of Ukraine, № 4, 28-38.

2000000 rub. na rabochee zhilstroitelstvo $\mathrm{v}$ xarkove (1927). [2,000,000 rubles. for working housing construction in Kharkov]. Xarkovskij proletarij-Kharkov Proletarian, January 8.

Danileva, Yu. (2011) Zhytlova problema v ukrayinskomu radyanskomu misti u 20-30-ti rr. XX stolittya [Housing problem in the Ukrainian Soviet city in the 20-30th years of the twentieth century]. Visnyk Sxidnoukrayinskogo nacionalnogo universytetu im. V. Dalya. - Bulletin of the East Ukrainian National University named after. V. Dahl, №11, Part 1, 28-38

Didenko, E. (2012) Zhylyshhnoe stroytelstvo v stolychnom Xarkove (1927 - 1934) [Housing construction in the capital Kharkov (1927 - 1934)]. Tradyciyi i novaciyi $u$ vyshhij arxitekturno-xudozhnij osviti: zbirka naukovyx pracz/ Xarkivska derzhavna akademiya dy'zajnu ta mystecztva. - Traditions and innovations in higher architectural and artistic education: a collection of scientific works, Kharkiv State Academy of Design and Art. Kharkiv, Exit. 6, 69-78

Dorogo koshtuye zhy'tlove budivny'cztvo(1928). [Costly housing construction]. Robitnycha gazeta "Proletar», 6 sichnya - Worker's newspaper Proletar, January 6

Druz, F. (1927) Zhilishhnaya kooperaciya ukrainy k desyatoj godovshhine oktyabrskoj revolyucii [Housing cooperation of Ukraine for the tenth anniversary of the October Revolution]. Zhilishhnaya kooperaciya ukrainy - Housing cooperation of Ukraine, № 15, 19 - 32

Dubrovsky, (1927) Mnimye vygody individualnogo stroitelstva [Imaginary benefits of individual construction]. Zhilishhnaya kooperaciya Ukrainy. - Housing cooperation of Ukraine, № 4, 28-39.

Zhilishhnyj vopros: sbornik dekretov, rasporyazhenij, instrukcij s razyasneniyami (1921). [Housing issue: Collection of decrees, orders, instructions with explanations]. Kh., 171.

Zhilishhnoe stroitelstvo na uroven zadach vtoroj p'yatilitki (1934). [Housing construction to the level of the second p'yatilinka's tasks]. Xarkovskij rabochij Kharkov Worker, March 29.

Zhilishhno - kommunalnoe xozyajstvo SSSR. spravochnye dannye. Moskva: nif SSSR gosfinizdat (1936). [Housing and communal services of the USSR]. Reference data. Moscow: NIF USSR Gosfinizidat, 55 tables 
Zhy`tlova kry`za v Xarkovi (1925). [Housing crisis in Kharkiv]. Visti VUCzVK - VUTSVK news, October 15.

Yarmish, O. N., Posohov, S.I. (2004).Istoriya mista Xarkova XX stolittya [History of Kharkiv city of the twentieth century]. Kh.: Folio, Golden Pages, 686.

Kak oslabit zhilishhnij krizis v xarkove (1924). [How to weaken housing crises in Kharkov]. Xarkovskij proletarij - Kharkov Proletarian, 1 Aug.

Kaplunov, I., Bukshtein, D. (1930). Zhytlovi umovy miskogo proletariatu USRR [Housing conditions of the urban proletariat of the Ukrainian SSR]. Visnyk statystyky - Bulletin of Statistics, No. 6, 48-59.

Kovalenko, I. (1926). Xarkiv. Naselennya, zhytlovi umovy, byudzhet dribnyx volodin [Kharkiv Population, housing conditions, budget of small estates]. Kh.: Har. okr.stat bureau, Vip.3, 7.

Kolyastruk, O. Pressa v umovax «nastupu socializmu» (kinecz 20-x - pochatok 30-x rr.) [The press in the "socialist offensive" (late 20's - early 30's)]. Retrieved from file: ///D:/System/Downloads/Nzvdpu_ist_2001_3_28\% 20(1).pdf

Kolyastruk O.A. 2003. Presa v radyans`kij polity`chnij sy`stemi u 20-30-ti pp. XX st [Press in the Soviet political system in the 20-30th pp. XX centuries]. Naukovi zapysky Vinnyczkogo derzhavnogo pedagogichnogo universytetu imeni Myxajla Kocyubynskogo - Scientific notes of Vinnitsa State Pedagogical University in the name of Mikhail Kotsyubinsky, Series: History, P.5,104110, Retrieved from:

http://nbuv.gov.ua/UJRN/Nzvdpu_ist_2003_5_28

Laboratorin, (1924). K razresheniyu zhilishhnogo krizis$\mathrm{na}$ [To the resolution of the housing crisis] Zhilishhe rabochego - Housing worker, №1,11-12

Levitan J. (1932). Vijna poverxiv [War of floors]. Xarkivskyj proletar - Kharkiv proletar, November 7.

Lyubavsky, O. (2016) Povsyakdenne zhy`ttya robitny'kiv Xarkova v 1920-ti - pochatku 1930-x rokiv [Everyday life of Kharkiv workers in the 1920s - early 1930s]. Kh.: The Rare of Ukraine, 226.

Marzeev, A.N. (1928). Novye rabochie zhilishha na ukraine [New Workers Housing in Ukraine], Kh., 121.

Mestetsky, Ya. (1929) Zhilishhnoe xozyajstvo ukrainy [Housing economy of Ukraine]. Kh.: State. Publishing House of Ukraine, 168.

Meerovich, M.G. (2008).Nakazanie zhilishhem: zhilishhnaya politika v sssr kak sredstvo upravleniya lyudmi (1917-1937 gody) [Housing punishment: housing policy in the USSR as a means of managing people (19171937)] M.: ROSSPEN; 303.

My protyi shvejczarskyx domykiv, i budynkiv - komun (1928). [We are against both Swiss houses and houses communes]. Robitny 'cha gazeta "Proletar» 31 zhovtnya -Worker's newspaper Proletarius, October 31th.
Movchan, O. M. (2011). Povsyakdenne zhy`ttya robitny' kiv USRR.1920-ti rr. [The daily life of the workers of the USSR in the 1920's.] K .: Institute of History of Ukraine of the National Academy of Sciences of Ukraine, 312 .

O novyx techeniyax $\mathrm{v}$ razreshenii zhilishhnogo voprosa (1927) [On the new trends in the resolution of the housing issue]. Zhilishhnaya kooperaciya Ukrainy - Housing cooperation of Ukraine, No. 11, 30-38.

O.G. (1934) Zhilishhnoe stroitelstvo na uroven zadach vtoroj pyatiletki [Housing construction to the level of the tasks of the second five-year plan]. Xarkovskij rabochijKharkov Worker, March 29.

Okhitovich M. (1930).Zametki po teorii rasseleniya [Notes on the Theory of Settlement]. Sovremennaya arxitektura - Modern Architecture, No. 1-2, 45-49.

Plan zhilishhnogo i kommunalnogo stroitelstva g. xarkova i ego prigorodnoj zony. vtoroe pyatiletie(1933-1937 gg.) [The plan of housing and communal construction of Kharkov and its suburban area. The second five-year anniversary (1933-1937)]. Under the general editorship of M.G. Shakhmatov. and Zigerman I.N. [Part 1.] [Kharkov]. Editorial and publishing sector of the Kharkiv City Council. 1932. Kharkiv city planning commission. Materials for Option 1 of the five-year plan for economic and national-cultural construction. Issue 1. [Part 1.]

Profsoyuzy za strojkoj (1927). [Trade unions at the construction site]. Xarkovskij proletarij - Kharkov Proletarian, September 16.

Orlov, Y. (1933). Vporyadkuvaty' zhy'tlove gospodarstvo Xarkova [Housing Housing in Kharkiv]. Xarkovskij proletarij - Kharkiv Proletar, January 6.

Stepanchuk, Yu. (2012) Periodychni vydannya yak istorychne dzherelo u doslidzhennya suspilnogo zhyttya USRR u 20-X rokax XX stolittya [Periodicals as a Historical Source in the Study of the Social Life of the Ukrainian SSR in the 20s of the XX Century]. Istorychna pamyat - Historical Memory, Voice 28, 155-160. Retrieved from: http://nbuv.gov.ua/UJRN/Ip_2012_2_18

Stroit deshevo, xorosho, krasivo (1934). [To build cheap, good, beautiful]. Xarkovskij rabochij - Kharkov Worker, May 29th.

Udar po zhytlo kryzi (1928). [Impact on housing crisis]. Robitny 'cha gazeta "Proletar» - Worker's newspaper "Proletar", October 13.

Khmury, V. (1925) Shhe do arxitekturnogo obly`chchya mista [More to the architectural face of the city]. Visti VUCzVK - VUTSVK news, November 1th.

Churilov, I.M. (1934). Zabytye obshhezhitiya [Forgotten hostel]. Xarkovskij rabochij - Kharkov worker, March 29 th. 